\title{
Efficacy of Combined Formulations of Fungicides in Managing Late Blight Disease of Potato Caused by Phytophthora infestans (Mont.) de Bary
}

\author{
Susmita Jha ${ }^{1 *}$, Surajit Khalko ${ }^{1}$, Mushineni Ashajyothi ${ }^{2}$, \\ Sekhar Bandyopadhyay ${ }^{1}$ and Ayon Roy ${ }^{1}$ \\ ${ }^{1}$ Department of Plant Pathology, Uttar Banga Krishi Viswavidyalaya, \\ Cooch Behar, West Bengal, India \\ ${ }^{2}$ Department of Plant Pathology, Indian Agricultural Research Institute, New Delhi, India \\ *Corresponding author
}

\begin{abstract}
A B S T R A C T
This study involves the efficacy testing of six new generation for the management of most devastative and cosmopolitan disease of Potato i.e., Late blight caused by Phytophthora

Keywords

Potato, Late Blight, AUDPC, Weather relation, Chemical management, Yield loss.

\section{Article Info}

Accepted:

07 October 2017

Available Online:

10 December 2017

infestans (Mont.) de Bary. To identify most important weather parameter for disease spread, the relation between daily temperature, rainfall and relative humidity and late blight development scenario throughout the season was studied. The study was conducted, in two consecutive crop seasons 2015-2016 and 2016-2017. Though all the fungicides effectively reduced the disease index over the control, out of six test chemicals, combination of Iprovalicarb 5.5\% + Propineb $61.25 \%$ (T6) was found to be the best with least disease (AUDPC - 728.519) progress and highest projected yield (16.96 t/ha) and BC ratio (1: 0.777). Pyraclostrobin 5\% + Metiram 55\% was statistically at par with T6 showing less (AUDPC - 757.037) with 16.13 t/ha projected yield and maximum BC ratio (1:0.7645). Since there are huge reports on Phytophthora showing resistance to Phenylamide fungicides (Metalaxyl), most commonly used fungicides for late blight control in India and abroad, this combination of Iprovalicarb 5.5\% + Propineb $61.25 \%$ can be suggested as an alternative for blight management. Mixtures of compatible chemicals with alternative and optimum dose sprays will effectively help in reducing losses caused by diseases as well as help in increasing potato tuber yield.
\end{abstract}

\section{Introduction}

Potato (Solanum tuberosum L.) is one of the most important food crops globally with huge yield potential giving remunerative income to the farmers and having excellent nutritional value. It ranks third after rice and wheat in terms of human consumption (FAOSTAT, 2015). Among root and tuber crops, potato ranks first in volume of production and consumption, followed by cassava, sweet potato and yam (FAO, 2008). As potato is a short duration crop, it produces more amount of dry matter, edible energy and edible protein in lesser duration of time than cereals like rice and wheat. Hence potato may play a major role to attain national food security of India. Present trend of shifting more to potato cultivation brings more profits to farmers. Potato plays a crucial role in farm economy due to its great yield potential but the supposed yield is not reached due to several 
constraints, majorly climatic change and various biotic factors. Among biotic factors many insects and disease causing agents viz. fungus like oomycete, viruses, fungus, bacteria, nematode, viroids and phytoplasmas are reported on potato.

Among the major diseases of potato, Late blight caused by Phytophthora infestans (Mont.) de Bary is the most devastating disease of potato worldwide. On several occasions the diseases has reached catastrophic extent. The saddest past is 1840's Irish Famine which killed around 1 million people and directed additional 1 million to leave the island. Even after triggering the Irish famine, the disease has continued to appear on potato fields all round the world. Fisher et al., 2012, reported that Late blight results in annual losses of potatoes that would be sufficient to feed anywhere from 80 to many hundreds of millions of people. Global tuber yield losses were reported to be $€ 12$ billion (Haverkort et al., 2009).

Attempts of chemical management of potato Late blight started since 1875 in Ireland and Peru in the form of Sodium chloride and Copper sulphate respectively basically for seed treatment. Since then Bordeaux mixture, Dithiocarbamates, Phthalimides, etc. as contact fungicides and Cyanoacetamide, Cinnamic acid derivatives, Phenylamides, Strobilurins, etc. has been used as systemic fungicides. But incidences of resistance build up in pathogen against fungicides with single mode of action suggested the need of using combined formulation of fungicides. So efficacy of some combined formulations of new generation fungicides against Late blight disease was studied.

\section{Materials and Methods}

Experiment was conducted at the instructional farm, Uttar Banga Krishi Viswavidyalaya,
Pundibari, Cooch Behar, West Bengal, India to determine the effectiveness of the test fungicides against Late blight of Potato.

There were seven treatments in cropping season of 2015-2016 and 2016-2017 consisting of 6 new generation chemicals and control.

Spray was initiated just after the detection of Late blight symptoms in the experimental area and repeated thrice at an interval of 7 days.

In control treatment, equal amount of plain water was sprayed. Late blight of potato was scored with the help of disease rating scale developed at CIP, 1985 given below: Percentage of Disease Incidence (PDI) and Area Under Disease Progress Curve (AUDPC) was calculated by using the formula given by the Wheeler (1969) and Wilcoxson et al., (1975) respectively.

$\mathrm{PDI}=\log _{100}^{\frac{\text { Sum of individual rating }}{\text { No. of leaves assesed }}} \mathrm{X}$

Maximum disease grade

$\mathrm{n}$

AUDPC $=\Sigma 1 / 2\left(\mathrm{~S}_{\mathrm{i}-}-\mathrm{S}_{\mathrm{i}-1}\right) \mathrm{d}$ i-1

AUDPC $=$ Area under disease progress curve

$\mathrm{Si}=$ Disease severity at the end of time $\mathrm{i}$

$\mathrm{k}=$ Number of successive evaluation of blight severity

$\mathrm{d}=$ Interval between two observations

Daily maximum temperature, minimum temperature and humidity, Yield per plot were recorded for the two crop seasons and its relation with PDI was observed. 


\section{Statistical analysis}

The trails were conducted following Randomized Block Design. Statistical analysis was done using SPSS statistical package. The comparison was done at 5\% and $1 \%$ probability level.

\section{Results and Discussion}

Six different fungicides were tested in crop season 2015-2016 and 2016-2017. All the fungicidal treatments were found effectively reduced disease progress than control. In the year 2015-2016 (Table 1) the treatment (Iprovalicarb 5.5\% + Propineb 61.25\%) WP (T6) showed lesser area under disease progress curve (728.519) than all other treatments. Another treatment (Pyraclostrobin $5 \%+$ Metiram 55\%) WG (T5) found statistically at par with (T6) showing less AUDPC (757.037) which is lesser than even other treatments. In terms of yield estimates same pattern was found for (T6) with 16.96t/ha which is highest among all, followed by (T5) 16.13 t/ha. Benefit Cost Ratio also indicates (Iprovalicarb 5.5\% + Propineb 61.25\%) WP (T6) is economical to go for field application (1: 0.777). Control plot has given highest AUDPC (1282) and lowest estimated yield (14.43 t/ha).

The epidemiological studies of the disease show that the disease is majorly dependent on the weather parameters- Temperature and Relative humidity. These two factors play a major role in maintaining micro climate of the canopy. The correlation analysis between the weather parameters and disease severity shows that high relative humidity, high rainfall and minimum temperature ( $\mathrm{T} \mathrm{min}$ ) is positively correlated with PDI (Table 2).

Plant micro climate with these favorable environmental factors helps in production of enormous asexual spores and rapid dispersal of the secondary inoculum. Wider spacing between plants and spraying underside of the leaves effectively reduce the disease incidence. The results of cropping season 2016-2017 also reveals lesser disease progress and higher yield and BCR, both in case of T6 and T5 with the AUDPC value of 667.16 and 686. 173, Yield 16.69 and 16.12, BCR 1: 0.5878 and 1: 0.5659 respectively, which are significantly different than other treatments (Table 3).

In 2015-16 relatively high disease severity was observed due to congenial environment where, Amistar top could not perform well in case of 2016-17 study it's performance in terms of disease reduction was at par with our best treatment i.e. T6. So we pooled the data of two years to see the response irrespective of the year. The pooled data of two years (Table 4) also indicates that curative spray helps in reducing the inoculum level which plays prime role in disease spread. With lowest AUDPC (697.84) combination of carbamate along with broad spectrum fungicide (Iprovalicarb 5.5\% + Propineb $61.25 \%$ ) WP was found most significant in case of yield and disease. The same was observed in (Pyraclostrobin 5\% + Metiram $55 \%)$ WG combination.

Other combinations such as (Pyraclostrobin 5\% + Metiram 55\%) WG and (Tebuconazole $50 \%+$ Trifloxystrobin 25\%) WG was found to be the least effective in controlling the disease, while (Azoxystrobin $+125 \mathrm{~g} / \mathrm{L}$ Difenoconazole) SC gave mediocre results in controlling the disease as compared to nonsprayed control. As we know that strobilurins are more specific to Basidiomycetes fungi, their effectiveness towards oomycetes is minimal. The findings of Rehman et al., (2008) are also in line with the present studies, as they reported that application of (Iprovalicarb 5.5\% + Propineb 61.25\%) WP is highly effective to minimize late blight. 
Fungicides used for field evaluation

\begin{tabular}{|c|l|c|}
\hline S.No. & \multicolumn{1}{|c|}{ Treatment } & Dose \\
\hline T1 & Amistar Top (200g/L Azoxystrobin + 125 g/L Difenoconazole) SC & $1 \mathrm{ml} / \mathrm{L}$ \\
\hline T2 & Nativo (Tebuconazole 50\% + Trifloxystrobin 25\% w/w) 75 WG & $0.5 \mathrm{~g} / \mathrm{L}$ \\
\hline T3 & Curzate (Cymoxanil 8\%+ Mancozeb 64\%)WP & $1.5 \mathrm{~g} / \mathrm{L}$ \\
\hline T4 & Acrobat (Dimethomorph 50\% WP) & $1 \mathrm{~g} / \mathrm{L}$ \\
\hline T5 & Clutch (Pyraclostrobin 5\% + Metiram 55\%) WG & $1 \mathrm{~g} / \mathrm{L}$ \\
\hline T6 & Melody duo (Iprovalicarb 5.5\%+ Propineb 61.25\%) WP & 2g/L \\
\hline T7 & Control & - \\
\hline
\end{tabular}

Late blight of potato was scored with the help of disease rating scale

\begin{tabular}{|l|l|l|l|}
\hline \multirow{2}{*}{$\begin{array}{c}\text { CIP scale } \\
\text { value }\end{array}$} & \multicolumn{2}{|c|}{ Blight (\%) } & \multicolumn{1}{c|}{ Symptoms } \\
\cline { 2 - 3 } & Mean & \multicolumn{1}{|c|}{ Limits } & \\
\hline 1 & 0 & & No late blight observable \\
\hline 3 & 2.5 & Traces- $<5$ & Late blight present. Maximum 10 lesions per plant. \\
\hline 4 & 25 & $5-<15$ & $\begin{array}{l}\text { Plants look healthy, but lesions are easily seen at closer } \\
\text { distance. Maximum foliage area affected by lesions or } \\
\text { destroyed corresponds to no more than 20 leaflets. }\end{array}$ \\
\hline 5 & 50 & $35-<65$ & $\begin{array}{l}\text { Late blight easily seen on most plants. About 25\% of } \\
\text { foliage is covered with lesions or destroyed. }\end{array}$ \\
\hline 6 & 75 & $65-<85$ & $\begin{array}{l}\text { Plot looks green; however, all plants are affected. Lower } \\
\text { leaves are dead. About half the foliage area is destroyed. }\end{array}$ \\
\hline 7 & 90 & $85-<95$ & $\begin{array}{l}\text { Plot looks green with brown flecks. About 75\% of each } \\
\text { plant is affected. Leaves of the lower half of plants are } \\
\text { destroyed. }\end{array}$ \\
\hline 8 & 97.5 & $95-<100$ & $\begin{array}{l}\text { Plot neither predominantly green nor brown. Only top } \\
\text { leaves are green. Many stems have large lesions }\end{array}$ \\
\hline 9 & 100 & $\begin{array}{l}\text { Plot is brown- colored. A few top leaves still have some } \\
\text { green areas. Most stems have lesions or are dead. }\end{array}$ \\
\hline All leaves and stems dead.
\end{tabular}

Table.1 Severity of potato late blight at different fungicidal treatment (2015-2016)

\begin{tabular}{|lcccc|}
\hline Fungicides & AUDPC & $\begin{array}{c}\text { Yield } \\
\left(\mathbf{k g} / \mathbf{1 2} \mathbf{~ m}^{\mathbf{2}}\right)\end{array}$ & $\begin{array}{c}\text { Estimated yield } \\
(\mathbf{t} / \mathbf{h a})\end{array}$ & $\begin{array}{c}\text { Benefit Cost } \\
\text { Ratio }\end{array}$ \\
\hline Amistar top & $791.605^{\mathrm{D}}$ & $18.727^{\mathrm{BC}}$ & 15.61 & $1: 0.8865$ \\
Nativo & $878.025^{\mathrm{B}}$ & $17.6^{\mathrm{C}}$ & 14.67 & $1: 0.9460$ \\
Curzate & $833.951^{\mathrm{C}}$ & $17.607^{\mathrm{C}}$ & 14.67 & $1: 0.9478$ \\
Acrobat & $860.741^{\mathrm{BC}}$ & $18.22^{\mathrm{BC}}$ & 15.18 & $1: 0.9082$ \\
Clutch & $757.037^{\mathrm{E}}$ & $19.36^{\mathrm{AB}}$ & 16.13 & $1: 0.7645$ \\
Melody duo & $728.519^{\mathrm{E}}$ & $20.353^{\mathrm{A}}$ & 16.96 & $1: 0.777$ \\
Control & $1282^{\mathrm{A}}$ & $17.32^{\mathrm{C}}$ & 14.43 & $1: 0.8460$ \\
\hline SEM \pm & $\mathbf{9 . 9 8}$ & $\mathbf{0 . 4 6}$ & & \\
CD & $\mathbf{3 0 . 7 6}$ & $\mathbf{1 . 4 1}$ & & \\
\hline
\end{tabular}


Table.2 Correlation analysis of PDI and weather parameters - 2015-2016

\begin{tabular}{|lllcr|}
\hline Treatments & AUDPC & $\begin{array}{l}\text { Yield }(\mathbf{k g} / \mathbf{1 2} \\
\left.\mathbf{m}^{2}\right)\end{array}$ & $\begin{array}{l}\text { Estimated } \\
\text { yield(t/ha) }\end{array}$ & $\begin{array}{c}\text { Benefit Cost } \\
\text { Ratio (BCR) }\end{array}$ \\
\hline Amistar top & $703.457^{\mathrm{C}}$ & $19.097^{\mathrm{AB}}$ & 15.91 & $1: 0.6234$ \\
Nativo & $775.185^{\mathrm{B}}$ & $17.16^{\mathrm{AB}}$ & 14.30 & $1: 0.7107$ \\
Curzate & $765.679^{\mathrm{B}}$ & $17.483^{\mathrm{AB}}$ & 14.57 & $1: 0.6901$ \\
Acrobat & $776.914^{\mathrm{B}}$ & $18.807^{\mathrm{AB}}$ & 15.67 & $1: 0.6238$ \\
Clutch & $686.173^{\mathrm{C}}$ & $19.343^{\mathrm{A}}$ & 16.12 & $1: 0.5659$ \\
Melody duo & $667.16^{\mathrm{C}}$ & $20.03^{\mathrm{A}}$ & 16.69 & $1: 0.7007$ \\
Control & $1156.00^{\mathrm{A}}$ & $16.05^{\mathrm{B}}$ & 13.38 & \\
\hline SEM \pm & $\mathbf{1 2 . 0 3 3 1 9}$ & $\mathbf{0 . 9 2 6}$ & & \\
CD & $\mathbf{3 7 . 0 7 7 9 5}$ & $\mathbf{2 . 8 5 5}$ & & \\
\hline
\end{tabular}

Table.3 Severity of potato late blight at different fungicidal treatment (2016-2017)

\begin{tabular}{|l|c|c|c|c|c|}
\hline \multicolumn{1}{|c|}{ PDI } & T max & T min & RH max & RH min & Rain \\
\hline PDI & $-.697^{*}$ & 0.316 & $.884^{* *}$ & $.817^{* *}$ & $.858^{* *}$ \\
T max & & $.863^{* *}$ & $-.945^{* *}$ & $-.982^{* *}$ & -0.255 \\
T min & & & $-.662^{* *}$ & $-.786^{* *}$ & 0.213 \\
RH max & & & $.982^{* *}$ & 0.557 \\
RH min & & & & 0.42 \\
Rain & & & \\
*. Correlation is significant at the 0.05 level (2-tailed). \\
**. Correlation is significant at the 0.01 level (2-tailed). \\
\hline
\end{tabular}

Table.4 Severity of potato late blight at different fungicidal treatment- pooled

\begin{tabular}{|lcc|}
\hline Treatments & AUDPC & Yield(Kg) \\
\hline T1 & $747.53^{\mathrm{D}}$ & $18.9117^{\mathrm{ABC}}$ \\
T2 & $826.60^{\mathrm{B}}$ & $17.3800^{\mathrm{CD}}$ \\
$\mathrm{T} 3$ & $799.81^{\mathrm{C}}$ & $17.5450^{\mathrm{CD}}$ \\
$\mathrm{T} 4$ & $818.83^{\mathrm{BC}}$ & $18.5133^{\mathrm{BC}}$ \\
$\mathrm{T} 5$ & $721.60^{\mathrm{E}}$ & $19.3517^{\mathrm{AB}}$ \\
T6 & $697.84^{\mathrm{F}}$ & $20.1917^{\mathrm{A}}$ \\
T7 & $1219.38^{\mathrm{A}}$ & $16.6850^{\mathrm{D}}$ \\
\hline SEM \pm & $\mathbf{7 . 8 2}$ & $\mathbf{0 . 5 2}$ \\
CD & $\mathbf{2 2 . 8 2}$ & $\mathbf{1 . 5 1}$ \\
\hline
\end{tabular}

The present finding is also corroborated with the work of Lal et al., (2017), who studied the efficacy of new fungicides against late blight of Potato in Subtropical Plains of India and evaluated the field efficacy of (Metiram 55\% + Pyraclostrobin 5\% WG), (Iprovaliacarb $5.5 \%+$ Propineb $61.25 \%$ WP), (Cymoxanil
8\% + Mancozeb 64\% WP), (Dimethomorph $50 \%$ WP) etc. Anwar et al., (2015) found (Pyraclostrobin 5\% + Metiram 55\% WG) as most effective for controlling late blight disease of potato. With this we can suggest that carbamates (Dithiocarbamates) in combination with any copper based broad 
spectrum fungicides, either in complex formulations or as alternate sprays can be used to manage the late blight disease.

Management of Late blight should not solely depend on chemical management.

As the nature of the pathogen is well studied by this time, it must have an integrated plan which consists of cultural measures like sanitation which is a prime factor to avoid primary inoculum for the next growing season and use of the bio-control agents like Pythium sp. (Nonpathogenic) and also need based use of fungicides in combinations.

Here, in this study two combined formulations (Iprovalicarb 5.5\% + Propineb $61.25 \%$ ) and (Pyraclostrobin 5\% + Metiram $55 \%$ ) showed to be effective in blight management.

These fungicides can be recommended, to incorporate in integrated management practices for late blight disease of Potato.

\section{Acknowledgement}

Uttar Banga Krishi Viswavidyala, Department of Plant Pathology

\section{Author contributions}

All authors equally contributed

\section{Abbreviations}

AUDPC - Area Under Disease Progress Curve

PDI - Percent Disease Index

SPSS - Statistical Package for the Social Sciences

BCR - Benefit Cost Ratio

\section{Ethical approval}

This article does not contain any studies with human participants or animals performed by any of the authors.

\section{References}

Anwar MM, Parween A, Hossain MM, Mahamud NU and Roy RK. 2015. Efficacy of fungicides in controlling late blight of potato. Progressive Agriculture. 26: 103-108.

CIP (International Potato Center). 1989. Fungal diseases of potato. Report of planning conference on fungal diseases of the potato. CIP, Lima, Peru. Pp. 216.

FAO (Food and Agriculture Organization). 2008. Potato World: AfricaInternational Year of the Potato 2008. http://www.potato2008.org/en/world/afr ica.html. Accessed at: 12/5/2014.

FAOSTAT. 2015. Data base of agricultural production [online]. Available at http://faostat3. fao.org/home/E (updated 31 September 2015; accessed 11 October 2015). Food and Agriculture Organization, Rome, Italy.

Fisher MC, Henk DA, Briggs CJ, Brownstein JS, Madoff LC and McCraw SL. 2012. Emerging fungal threats to animal, plant and ecosystem health. Nature. 484:186-194.

Haverkort AJ, Struik PC, Visser RGF and Jacobsen E. 2009. Applied Biotechnology to combat Late Blight in potato caused by Phytophthora infestans. Potato Research. 52: 249264.

Lal M, Yadav S and Singh BP. 2017. Efficacy of new fungicides against Late Blight of potato in Subtropical plains of India. Journal of Pure and applied Microbiology. 11: 599-603.

Rahman MA, Dey TK, Ali MA, Khalequzzaman KM and Hussain MA. 
2008. Control of late blight disease of potato by using new fungicides. Int. J. Sustain. Crop Prod. 3(2): 10-15.

Wheeler BEJ. 1969. An Introduction to Plant Diseases. John Wiley and Sons, Limited. London. pp. 301.
Wilcoxson, Skovmand RD and Atif AH. 1975. Evaluation of wheat cultivars for ability to retard development of stem rust. Annual Applied Biology. 80: 275281.

\section{How to cite this article:}

Susmita Jha, Surajit Khalko, Mushineni Ashajyothi, Sekhar Bandyopadhyay and Ayon Roy. 2017. Efficacy of Combined Formulations of Fungicides in Managing Late Blight Disease of Potato Caused by Phytophthora infestans (Mont.) de Bary. Int.J.Curr.Microbiol.App.Sci. 6(12): 765-771. doi: https://doi.org/10.20546/ijcmas.2017.612.081 